\title{
INFLUENCES OF DIFFERENT FACTORS ON DYNAMICS OF CHILDREN'S AGGRESSION AND TEENAGE CRIMINALITY (ON AN EXAMPLE OF THE MOSCOW AND ALTAI REGIONS)
}

\author{
Victor V. Glebov \\ Peoples' Friendship University of Russia \\ Moscow \\ Gennady G. Arakelov \\ Lomonosov Moscow State University \\ Moscow
}

\begin{abstract}
The paper studies the degree of aggression among teenagers in different social, economic, and cultural conditions. The research was conducted for the Altai and Moscow regions. It also suggests the analysis of dynamics of juvenile delinquency which is often expressed by social inability to adapt in society. Sex distinctions in dynamics of aggressive behavior of teenagers were specially considered.
\end{abstract}

Keywords: aggressive behavior, uneasiness, social teenager's disadaptation, minor offenders, the social environment.

A profound social-psychological crisis which has affected our society after disintegration of the USSR, is caused by the system factors which have interfered with all spheres of public state. Consequences of this collapse, it is shown, emerge first and foremost in the destruction of basic values in the life of Russian society, which brings the fall of moral and cultural guidelines, increase in number of aggressive-depressive dispositions, the spread of extremism and growth of confrontation. All of these finally lead to increase of social tension in society (Luneev, 1997; Arakelov \& Glebov, 2009).

Dramatic growth of crime, especially in the youth environment became one of the most evident consequences of social and economic changes in our country. Allowing for the public importance and scientific interest to a given problem, we have undertaken a research of dynamics of teenage delinquency in which violent whirlpools aggressive 
behaviour of teenagers is concealed (Kudryavtsev, 1998; Glebov \& Rodionova, 2009).

If we address statistics we can register a positive dynamics of crime growth in this country, which was marked by the outburst in the late eighties of the 20th century. Along with the increase in the total level of criminality an alarming tendency of steady growth of offences amongst children and youth is observed. Thus, during the period of 1988-1992 the crime level has increased in 1.5 times (Konev, 1993). According to the on-line data of Ministry of the Interior of the Russian Federation for 1997, the total number of delinquents (in solved crimes) amounted to more than one million - 1372161 (Zabryansky \& Emelianova, 2000). The growth of crime indices in youth environment is marked in 53 regions (Prestupnost' i pravonarušeniâ, 1998). Relative number of the average juvenile delinquency in the country scale for 2005 has amounted to almost $12 \%$. As the minister of the Inferior of the Russian Federation Rashid Nurgaliev has put it: "...the crimes committed by people underage are frequently distinguished by special cruelty...” In 2005175 thousand minors were involved in crime, which makes it $55 \%$ more than in 2004 (Ria-novosti, 9.14.2005).

Analysis of the age profile of criminals reveals that 45916 delinquents committed crime at the age of 14-15; 116062 - at the age of 16-17. As a whole, among other culprits those of 14-17 years of age make $11.8 \%$ (Prestupnost' sredi nesoveršennoletnih, 1999). It is important to mention the fact that among all kinds of committed crimes "specially heinous" and "heinous" comprise the highest share in teenage group, in comparison with other age groups (Delovaâ pressa, 3.23.2007). Besides, the crime growth among girl teenagers causes profound concern (Prestupnost' sredi nesoveršennoletnih, 1999).

In this connection, according to the head of Ministry of the Interior of Russia Rashid Nurgaliev, the staff of school inspectors within the ministry of the Interior has been increased. Today the number of specialists, that will supervise questions of teenage delinquency in schools has grown to 6.6 thousand people. Crime prevention among children and teenagers becomes one of the most urgent lines of the department's activity.

School inspectors work already in 79 regions of Russia. They are engaged in explanatory work at schools, lecturing on the legal code, their duties also imply exposing and prevention of drug and pornography dis- 
semination at schools. In the framework of experiment family inspectors are employed in a number of regions, they will supervise the program of prevention of family violence and protection of children (Ria-novosti, 9.14.2005).

The practical part of the work, undertaken within the present research, dealt with an objective of revealing a degree of aggression in the teenage environment in different social, economic and cultural conditions, investigated for the Altai and Moscow regions, and conducting the analysis of dynamics of juvenile delinquency which is often expressed by inability for social adaptation in society. Sex distinctions in dynamics of aggressive behavior were thus considered. To reveal the influence of different environmental factors (ecological, social and cultural) we conducted researches in two regions - the Altai territory (Biysk) and the Central region (Moscow).

The present research considers a personality trait which is characterized by the presence of destructive tendencies, that is, aggression, mostly in the field of interpersonal relations. Aggression possesses qualitative and quantitative characteristics, which vary in the degree of expression: from almost complete absence to excessive manifestation. Each person should possess a certain degree of aggression. Its absence leads to passivity and acquiescence, as excessive manifestation - to inability of cooperation with people, proneness to conflict and destructive, asocial behavior.

Our hypothesis would assert that at the heart of teenage delinquency aggression lies the biologically determined and integral property of a person. Its degree (increased or abated) is regulated by psycho-socialcultural relationship within a social and ecological milieu. Ability for social adaptation through various behavioral strategies depends on both individual mental qualities, and the set of moral values of a teenager. With moral and cultural degradation of the society as well as derogation of family, social barriers to domination of the biological source of aggression in personality are removed, which stimulates asocial behavior (Urvantsev, 1981).

\section{Methods}

Minor offenders which participated in the experiment were 123 persons, at the age of 14-16, registered in a juvenile delinquents department in Biysk and Moscow (experimental group) and 14-16 year-old pupils 
(109 persons) of the comprehensive school No. 34 (Biysk) and school No. 126 in Moscow (control group). The total number of respondents for the sample amounted to 232 teenagers. The research was conducted in 2005-2008.

To carry out the investigation the following techniques have been employed: Bass-Darky Questionnaire, for research of aggression of adolescence; Hand Test, for analysis of aggression of teenagers, an estimation of the level of aggression of an individual and specificity of emotions opposite to aggression: fear, dependence, goodwill etc.; Lüscher colour test, diagnosing the psychic and physiological state of a teenager; Khanin's adaptation of Spielberger's State / Trait Anxiety Inventory, revealing the level of personal and situational uneasiness of a teenager; interviewing statistical package SHSS, version 7.

\section{Results}

The characteristics of teenage offenders. We started the stage-bystage testing with interviewing and examination of both minor offenders, and socially adapted teenagers, in the course of which the given sample has been divided into the following groups:

1) Teenagers focused on family, class, or school, having positive aspiration for the future, ambition for personal growth. Such teenagers demonstrate respect to law and social order.

2) Teenagers focused on objectives and positions of small teenage groupings, organized as local street community bound to a certain clubdisco or sports. This milieu displays no socially focused values. We can place them as outsiders.

3) Teenagers involved with the juvenile delinquency environment, focused on illegal activity for a profit or as a way of maintenance of a social status. This group is not homogeneous in its structure, it comprises various types of organization, structure, and ways of criminal orientation (Goryainov, 1993; Konev, 1993; Kudryavtsev, 1998; Masagutov, 2004).

Considering teenage population and the social environment through the prism of criminalization, it is important to note that marginal areas of relationship and behavior provide the greatest inflow of teenagers.

Having analyzed quantitative and qualitative structure of criminal activity of teenagers in the experimental group of our research, we have 
received the following results: the majority of teenage offenders committed crimes against property, its share has made up 87\% (107 teenagers). The second place was assigned to crimes against public safety (hooliganism, vandalism), they made up 75\% (92 teenagers); the third place was recognized for the crimes connected with human assault (fights) - 74\% (91 teenagers); the fourth place - for the crimes connected with drugs and alcohol overdose (psychoactive substances) 66\% (81 teenagers); the fifth place - for the attempts on human life and health (homicide, heavy physical injuries), which made up 34\% (42 teenagers).

Thus, it has become evident, that in Moscow $87 \%$ of all transgressions had mostly economic character - crimes against property (larceny, swindle), next come the crimes connected with human assault (fights) $80 \%$, the third place was assigned to drug and alcohol overdose (psychoactive substances) $-57 \%$. In Biysk the latter made up 74\%, as next comes hooliganism and vandalism $-70 \%$, and fight $-69 \%$.

In the control group the most transgressions do not fall into any category of criminal responsibility, revealing the following character: theft $-52 \%$, admissions of school employment $-41 \%$, petty scuffles among pupils of $30 \%$ (Moscow); for Biysk the data are as follows: petty scuffles among pupils of $41 \%$, theft $-33 \%$, admissions of school employment $-30 \%$.

It is also important to note, that $58 \%$ of offenders had the following features of mental status: mental frustration connected with disharmony, mental retardation in combination with psycho-genetic frustration of non-psychotic character, and addiction behavior (alcohol, toxics, and drugs). For them the characteristic feature would reveal the personality structure unstable in personal relations, interests and motivations.

In the group of socially adapted teenagers such disarrangements have been revealed in $21 \%$ of respondents.

Hand Test. Results (Table 1) of the Hand Test for the experimental group have shown high level of aggression both among girls (1.4 points), and among boys (1.6 points). Results of the control group for the present test were the following: girls have displayed the average level of aggression ( 0.7 points), boys likewise demonstrated the average level of aggression (1.2 points). 
Table 1

Results of gender distinctions of examinees of 2 groups by a projective technique of the Hand Test $(n=232)$

\begin{tabular}{|c|c|c|c|c|c|c|}
\hline \multirow{3}{*}{ No. } & \multicolumn{3}{|c|}{ Experimental group } & \multicolumn{3}{c|}{ Control group } \\
\cline { 2 - 7 } & $\begin{array}{c}\text { girls } \\
(\mathrm{n}=46)\end{array}$ & $\begin{array}{c}\text { boys } \\
(\mathrm{n}=77)\end{array}$ & $\begin{array}{c}\text { total } \\
(\mathrm{n}=123)\end{array}$ & $\begin{array}{c}\text { girls } \\
(\mathrm{n}=51)\end{array}$ & $\begin{array}{c}\text { boys } \\
(\mathrm{n}=58)\end{array}$ & $\begin{array}{c}\text { total } \\
(\mathrm{n}=109)\end{array}$ \\
\cline { 2 - 7 } & \multicolumn{4}{|c|}{ Aggression mean score by Vagner's technique } \\
\hline 1 & 1.4 & 1.6 & 1.5 & 0.7 & 1.2 & 1.0 \\
\hline
\end{tabular}

Gradation (points): 0.1-0.6 - low degree of aggression; 0.7-1.2 - average degree of aggression; 1.3-1.8 - high degree of aggression.

Bass-Darky questionnaire. Table 2 suggests the results of sex distinctions of examinees of 2 groups in accordance with definition of the general index of aggression and hostility of the Bass-Darky questionnaire.

Table 2

Indicators of gender distinctions of examinees of 2 groups based on Bass-Darky Questionnaire $(n=232)$

\begin{tabular}{|c|l|c|c|c|c|c|c|}
\hline \multirow{2}{*}{ No. } & \multirow{2}{*}{ Characteristics } & \multicolumn{3}{|c|}{ Experimental group } & \multicolumn{3}{c|}{ Control group } \\
\cline { 3 - 8 } & $\begin{array}{c}\text { girls } \\
(\mathrm{n}=46)\end{array}$ & $\begin{array}{c}\text { boys } \\
(\mathrm{n}=77)\end{array}$ & $\begin{array}{c}\text { total } \\
(\mathrm{n}=123)\end{array}$ & $\begin{array}{c}\text { girls } \\
(\mathrm{n}=51)\end{array}$ & $\begin{array}{c}\text { boys } \\
(\mathrm{n}=58)\end{array}$ & $\begin{array}{c}\text { total } \\
(\mathrm{n}=109)\end{array}$ \\
\hline 1 & Aggression index & 15.0 & 20.3 & 17.6 & 8.1 & 13.7 & 10.9 \\
\hline 2 & Hostility index & 14.2 & 12.7 & 13.4 & 7.8 & 9.2 & 8.5 \\
\hline
\end{tabular}

Gradation:

Aggression index: 0.1-7.0 - low degree of aggression; 7.1-14.0 - average degree of aggression; 14.1-21.0 - high degree of aggression.

Hostility index: 0.1-5.0 - low degree of hostility; 5.1-10.0 - average degree of hostility; 10.1-15.0 - high degree of hostility.

Experimental group. Aggression index in the experimental group among girls and boys has been marked as "high degree" (15.0 and 20.3 accordingly). Hostility index also displayed a high degree of animosity both with boys and girls. The parameter for girls (14.2) was higher, than that for boys (12.7).

Control group. Aggression index in the control group among girls and boys has been fixed at levels "average and high degree" (8.1 and 13.7 
accordingly). Hostility index is marked on the level "average degree of animosity" both for boys (9.2) and girls (7.8).

In Table 3 presents the results of sex distinctions within different types of aggression among examinees of 2 groups (Bass-Darky's method).

Table 3

Sex distinctions of types of aggression based on Bass-Darky Questionnaire $(\mathbf{n}=232)$

\begin{tabular}{|c|l|c|c|c|c|}
\hline \multirow{2}{*}{ No. } & \multicolumn{2}{|c|}{ Characteristics } & \multicolumn{2}{c|}{$\begin{array}{c}\text { Experimental } \\
\text { group }\end{array}$} & \multicolumn{2}{c|}{ Control group } \\
\cline { 3 - 6 } & & $\begin{array}{c}\text { girls } \\
(\mathrm{n}=46)\end{array}$ & $\begin{array}{c}\text { boys } \\
(\mathrm{n}=77)\end{array}$ & $\begin{array}{c}\text { girls } \\
(\mathrm{n}=51)\end{array}$ & $\begin{array}{c}\text { boys } \\
(\mathrm{n}=58)\end{array}$ \\
\hline 1 & Physical aggression $(4.0-6.0-$ norm $)$ & 7.1 & 9.8 & 4.3 & 5.7 \\
\hline 2 & Indirect aggression (4.0-5.0 - norm) & 7.7 & 6.3 & 4.4 & 5.2 \\
\hline 3 & Verbal aggression (4.0-6.0- norm) & 10.6 & 12.5 & 8.0 & 7.4 \\
\hline 4 & Negativism (2.0-3.0 - norm) & 4.2 & 4.5 & 3.1 & 2.2 \\
\hline 5 & Insult (4.0-5.0 - norm) & 6.4 & 5.9 & 4.9 & 4.0 \\
\hline 6 & Suspiciousness (4.0-6.0- norm) & 9.4 & 8.4 & 5.3 & 5.7 \\
\hline 7 & Irritation (4.0-6.0 - norm) & 7.1 & 10.5 & 4.7 & 5.3 \\
\hline
\end{tabular}

Experimental group. Results received for the group, show the high level for all types of aggression, irrespective of sex. However, for such parameters as "indirect aggression," "insult" and "suspiciousness" (7.7; 6.4; 9.4 points, accordingly) indices for girls were higher, than those for boys. For other parameters the reversed picture was observed.

Control group. Results received for the group, as a whole, did not exceed normal indices for various types of aggression both among boys and among girls, except for such parameters as "verbal aggression" for girls and boys (8.0 and 7.4, accordingly) and "negativism" for girls (3.1). Aggression index for the group among girls and boys has been fixed at the level of "average and high degree" (8.1 and 13.7 points, accordingly).

Lüscher colour test. In Table 4 results of sex distinctions for types of aggression among examinees of the 2 groups are presented. Distinctions in colour preference were the following: in the experimental group brown and dark blue colours for girls, both red and black - for boys, with greater indices assigned. In the control group dominated: both dark blue and violet for girls and dark blue and red for boys. 
Table 4

Gender distinctions by aggression kinds under the Lüscher test $(n=232)$

\begin{tabular}{|c|c|c|c|c|c|}
\hline \multirow{2}{*}{ No. } & \multirow{2}{*}{ Characteristics } & \multicolumn{2}{|c|}{ Experimental group } & \multicolumn{2}{c|}{ Control group } \\
\cline { 3 - 6 } & $\begin{array}{c}\text { girls } \\
(\mathrm{n}=46)\end{array}$ & $\begin{array}{c}\text { boys } \\
(\mathrm{n}=77)\end{array}$ & $\begin{array}{c}\text { girls } \\
(\mathrm{n}=51)\end{array}$ & $\begin{array}{c}\text { boys } \\
(\mathrm{n}=58)\end{array}$ \\
\hline 1 & $\begin{array}{l}\text { Prevailing colour char- } \\
\text { acteristics }\end{array}$ & $\begin{array}{c}\text { brown dark } \\
\text { blue }\end{array}$ & red, black & $\begin{array}{c}\text { dark blue, } \\
\text { violet }\end{array}$ & $\begin{array}{c}\text { dark blue, } \\
\text { red }\end{array}$ \\
\hline
\end{tabular}

Eysenck Personality Questionnaire. The experimental group results are presented in Table 5: there were 53 extraverts ( 22 of them were girls and 31 - boys); the number of introverts was about 2.65 times less (among them were 9 girls and 11 boys). Results for the control group in the same test were: 47 extroverts (20 girls and 27 boys); the number of introverts was 33 teenagers ( 21 girls and 12 boys). Neurosis indices for two investigated groups - experimental and control - has made up18.6 and 12.5 points, accordingly.

Spielberger's STAI. Indices of personality uneasiness according to the test of Spielberger's STAI for the experimental group were very high both for girls (3.6 points) and boys (3.2 points). Similar indices are revealed for situational uneasiness, both for girls (3.9 points) and boys (3.5 points).

Table 5

Average data of psychological testing of 2 groups $(n=232)$

\begin{tabular}{|c|c|c|c|c|c|c|c|c|}
\hline \multirow{4}{*}{$\begin{array}{c}\text { Groups } \\
\begin{array}{c}\text { Experi- } \\
\text { mental } \\
\text { group }\end{array}\end{array}$} & \multicolumn{8}{|c|}{ Psychological tests } \\
\hline & \multicolumn{4}{|c|}{ EPQ } & \multicolumn{4}{|c|}{ STAI } \\
\hline & \multirow{2}{*}{$\begin{array}{c}\text { Extrovert } \\
65\end{array}$} & \multicolumn{2}{|c|}{ Introvert } & $\begin{array}{c}\text { Neuro- } \\
\text { sis } \\
\end{array}$ & \multicolumn{2}{|c|}{$\begin{array}{l}\text { Personal un- } \\
\text { easiness }\end{array}$} & \multicolumn{2}{|c|}{$\begin{array}{l}\text { Situational } \\
\text { uneasiness }\end{array}$} \\
\hline & & \multicolumn{2}{|c|}{58} & \multirow[t]{2}{*}{18.6} & 3.6 & 3.2 & 3.9 & 3.5 \\
\hline & \begin{tabular}{|c|c|} 
girls & boys \\
$(\mathrm{n}=34)$ & $(\mathrm{n}=31)$ \\
\end{tabular} & $\begin{array}{c}\text { girls } \\
(\mathrm{n}=12)\end{array}$ & $\begin{array}{c}\text { boys } \\
(\mathrm{n}=46)\end{array}$ & & $\begin{array}{c}\text { girls } \\
(\mathrm{n}=10)\end{array}$ & $\begin{array}{c}\text { boys } \\
(\mathrm{n}=32)\end{array}$ & $\begin{array}{c}\text { girls } \\
(\mathrm{n}=36)\end{array}$ & \begin{tabular}{|c|} 
boys \\
$(\mathrm{n}=45)$
\end{tabular} \\
\hline $\begin{array}{l}\text { Control } \\
\text { group }\end{array}$ & 57 & \multicolumn{2}{|c|}{52} & 12.5 & 3.1 & 2.3 & 3.4 & 2.7 \\
\hline & \begin{tabular}{|c|c|} 
girls & boys \\
$(\mathrm{n}=30)$ & $(\mathrm{n}=27)$
\end{tabular} & $\begin{array}{c}\text { girls } \\
(\mathrm{n}=21)\end{array}$ & $\begin{array}{c}\text { boys } \\
(\mathrm{n}=31)\end{array}$ & & $\begin{array}{c}\text { girls } \\
(\mathrm{n}=21)\end{array}$ & $\begin{array}{c}\text { boys } \\
(\mathrm{n}=26)\end{array}$ & $\begin{array}{c}\text { girls } \\
(\mathrm{n}=30)\end{array}$ & $\begin{array}{c}\text { boys } \\
(\mathrm{n}=32)\end{array}$ \\
\hline
\end{tabular}

Gradation on Spielberger's STAI: 3.5-4.0 points - very high uneasiness; 3.0-3.4 points high uneasiness; $2.0-2.9$ points - average uneasiness; $1.5-1.9$ points - low uneasiness; $0.0-1.4$ points - very low uneasiness. 
Results for the group control in testing for uneasiness have revealed the following: personality uneasiness has been fixed as high for girls (3.1), and average for boys (2.3). Similar indices have been received for situational uneasiness: 3.4 points for girls, and 2.7 points for boys.

Data processing. The analysis of data processing shows that in the experimental group there is a correlation between the indices of insult $(r=0.833, p<0.05)$ and suspiciousness $(r=0.715, p<0.05)$ in BassDarky Questionnaire and extrovert in EPQ.

In the experimental group high degree of personality and situational uneasiness which had positive correlation in Lüscher test $(r=0.068$, $p<0.05)$ with prevalence of red, black, brown and dark blue colours, indicating aggression, and depression in mood and behavior of teenagers is also revealed.

Besides it we marked in the experimental group positive correlation between indices of physical $(r=0.656, p<0.05)$ and indirect aggression $(r=0.732, p<0.05)$ according to Bass-Darky Questionnaire and personality uneasiness in STAI.

\section{Discussion}

The Hand Test has revealed different levels of aggression in experimental and control groups. In the first group (experimental) high level of aggression is displayed in all samples, both among boys, and among girls. In the second group (control) the aggression average level has been revealed, for girls it was significantly lower, than for boys.

Significant distinctions between groups have been fixed as regards sex factor for all types of aggression, according to the test of Bass-Dark. Thus, in the experimental group there were revealed high indices for all types of aggression, they exceeded normal indices in 1,5 times, both for boys, and girls. Comparison of results of the 2 groups (Tab. 3), exposes domination of indices of the experimental group for all types of aggression (except for verbal aggression both for boys (7.4 points) and girls (8.1 points) and negativism for girls (3.1 points). Physical aggression for girls is increased in 1.6 times, and for boys in 1.7; indirect aggression -1.8 and 1.2, accordingly; suspiciousness - in 1.8 and 1.5 accordingly.

Prevalence of brown and dark blue colours for girls in the experimental group was interpreted, in accordance with the colour test of Lüscher, 
as pressure, fear of loneliness, desire to escape an adverse situation, while prevalence of red and black colours was assigned to display of aggression, and depression in mood and behavior of boy-teenagers.

In the control group of girls the preference basically was given to dark blue and violet colours, indicating slight anxiety, need for a sensitive environment and craving fore beauty; dark blue and red colours often come with boys of the group, to symbolize the feeling of integrity, active and not always realized desire for close relations, the deficit of attention from the people around (Bazhin \& Etkind, 1985; Bazym \& Kutko, 1997). Our data will be coordinated with the results received by V.F. Petrenko and V.V. Kucherenko (1988), where the opportunity of exposure of emotional conditions of examinees was studied by the method of colour preferences (the test of Lüscher). Thus, the suggestion of a sense of guilt was revealed in by respondents in preference of gray and dark blue colours, as aggression and grief - in red and black (Sobkin \& Kuznetsova, 1999).

It is worth to mention L.P. Urvantsev's (1981) statement which asserts correlation between colour preferences and "extravert" and "neurosis" factors, suggested by Eysenck. Examinees with high signs of "neurosis" would neutrally estimate only a small number of colours. The number of preferred colours with introverts is twice less, than with extraverts. The latter would choose red and yellow coloures and less frequently - dark blue and green (Urvantsev, 1981; Bazyma \& Kutko, 1997; Shipunova, 2000).

The most widespread type of aggression in our research is the direct verbal insult (for example, humiliating nicknames) or physical violence (kicks and blows). As we assumed, only some of teenagers of the experimental group have mentioned that they were exposed to more refined and indirect attacks (for example, social expulsion).

It is particularly important to note the stable correlation of indices for various forms of aggressive behavior of teenagers, that we have revealed through investigation of different social strata. The point is that teenagers are especially dependent on a microhabitat and a concrete situation. And family comes to be one of the key elements of a microhabitat in the development of relations, and personality formation. Thus, its structure (two-parent, one-parent) is important and determinant - moral atmosphere and mutual relation between members of the family.

When we examined the cases of offenders (experimental group) and interviewed all groups of respondents, we have concluded, that 56 (of 73) 
teenagers in the experimental group live in one-parent families, though others lived in two-parent families, these were facing certain problems (on the verge of the divorce, or hard drinking parents etc.).

In the control group of 80 respondents 19 teenagers come from oneparent families.

Another factor that would affect the display of child-teenage aggression, was the social status of a teenager (Glebov \& Rodionova, 2009).

The majority of parents of teenagers in the experimental group represent industrial workers (43 respondents), low skilled workers (50 respondents), intelligentsia ( 3 respondents), salespersons (4 respondents) and unemployed (23).

In the control group parents of teenagers were mainly associated with intelligentsia (63 respondents), salespersons (37 respondents), working specialties (4) executives (3) and low skilled workers (2).

It has been revealed, that aggressive behavior was displayed in the least by the teenagers from intelligentsia environment (teachers, doctors), as well as low skilled workers (cleaners, handymen), as the most aggressive are teenagers from families of working, supervising workers, salespersons, and businessmen. It was also established that the level of the physical form of aggressive behavior is mostly displayed by teenagers from working families, salespersons, and businessmen. The same tendency was observed for the verbal form of aggressive behavior of teenagers from working families and families pf salespersons. On the level of indirect aggression of teenagers similar pattern for almost all social strata was observed, but the maximum has been noted only for teenagers from families of executives.

One of the causes of high level aggression among teenagers of the experimental group may probably be assigned to the fact, that most offenders witnessed but too often hard drinking, outbursts of ruffianism, and violence both in family and outside relations, the worship of material assets, cynicism and aversion of cultural values of society.

In case of the control group of teenagers it is possible to explain the normal level of aggression by harmonious relations in the family; as well as the set of cultural values adopted in society and the developed ability of this environment to avoid conflicts, to smooth away contradictions not to aggravate a situation.

Summing up all stated above, we can assert that the hypothesis of our research has been verified. The notable high level of aggression in the 
sample of teenager-offenders in comparison with the sample of socially adapted teenagers is caused by the fact that aggression in this case acts as one of the basic behavioral strategy of a teenager-offender. Psychosocial-cultural factors and individual-psychological features regulating aggressive behavior of such teenagers are deformed (one-parent families, disharmony in family relations, aversion of cultural-moral values of a society and deviations in mental development). It leads to complete elimination of social barriers and domination of the biological basis of aggression of an individual, which affects the dynamics of asocial behavior.

\section{Conclusions}

The conducted research allows to draw the following conclusions:

1. Psychological methods employed in our study have revealed the high level of all types of aggression in the experimental group into which teenager - offenders were included.

2. The high level of aggression was inherent both for girl-teenagers, and boy-teenagers of the experimental group.

3. Features of individual-mental qualities of teenager-offenders (prevalence of extraversion, high levels of personality and situational uneasiness, frustration of personality and behavior, mental deficiency and other deviations), as well as public standard isolation and society cultural values provoke the growth of aggressive behavior among teenagers.

4. Great role is assigned to family relations and family structure. In one-parent families or families marked by disharmony in child-parental relations high degree of aggressive behavior is observed.

5. The social status of a teenager also affects the level of teenage aggression. High enough aggression of teenagers from working families, families of salespersons or businessmen and teenagers from families of executives are particularly marked.

6 . The set of cultural and moral values also contributes to dynamics of aggression and affects the level of weight of consequences of teenage offences. The teenagers inclined to worship of material assets, to cynicism and aversion of cultural-moral values of a society would join the number of aggressive people, this factor also provides the growth of crime in society.

7. The analysis of data processing shows that in the experimental group there is a correlation between the indices of insult and sus- 
piciousness in the Bass-Darky Questionnaire, and extraverts in the test of Eysenck. High degree of personality and situational uneasiness which had positive correlation with the test of Lüscher, and also positive correlation between indices of physical and indirect aggression in the Bass-Dark test and personality uneasiness in the test of Spielberger is noted.

\section{References}

Arakelov, G.G., \& Glebov, V.V. (2009). Agressivnye bezdomnye podrostki kak pitatel'naâ sreda dlâ terroristov [Aggressive Homeless Teenagers as a Fertile Ground

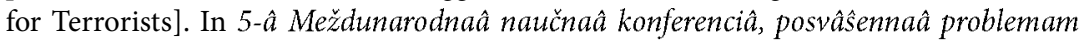
bezopasnosti i protivodejstviâ terrorizmu [5-th International Scientific Conference on Problems of Safety and Counteraction to Terrorism] (pp. 89-93). Moscow: MGU.

Bazhin, E.F., \& Etkind, A.M. (1985). Cvetovoj test otnošenij. Metodičeskie rekomendacii [Colour Test of Relations. Methodical Recommendations]. Leningrad.

Bazyma, B.A., \& Kutko, I.I. (1997). Cvetovye predpočteniâ podrostkov s akcentuaciâmi haraktera [Colour Preferences in Teenagers with Character's Accentuation]. Žurnal nevrologii i psihiatrii, 97 (1), 24-28.

Delovaâ pressa [The Business Press] 3.23.2007. http://www.businesspress.ru/ newspaper/default_mId_43_numId_5539.html.

Dinamika cennostej reformiruemoj Rossii (1995). [Dynamics of Values of the Reformed Russia]. Moscow: Nauka.

Dubinin, N.P., Karpets, I.I., \& Kudryavtsev, V.N. (1989). Genetika, povedenie, otvetstvennost' [Genetics, Behavior, Responsibility]. Moscow: Politizdat.

Glebov, V.V., \& Rodionova, O.M. (2009). Alkogol', podrostkovaâ agressivnost' i prestupnost' v škol'noj srede [Alcohol, Teenage Aggression and Criminality in the School Environment]. In 3 meždisciplinarnyj rossijskij kongress "Človek i alkogol' (alkogol'nye bolezni)" [3rd Interdisciplinary Russian Congress "The Person and Alcohol (Alcoholic Illnesses)"] (pp. 133-136). Saint Petersburg.

Goryainov, K.K. (1993). Latentnaâ prestupnost': rezul'taty issledovaniâ i mery bor'by [Latent Crime: Results of Research and Countermeasures]. In Latentnaâ prestupnost': poznanie, politika, strategiâ [Latent Crime: Knowledge, Policy, Strategy] (p. 24). Moscow: VNII MVD Rossii.

Konev, A.A. (1993). Prestupnost' v Rossii i ee real'noe sostoânie [Crime in Russia and its Real Condition]. N. Novgorod: Sètrik.

Kudryavtsev, V.N. (1998). Genezis prestupleniâ. Opyt modelirovaniâ prestupleniâ [Crime Genesis. Experience in Crime Modeling]. Moscow: Forum. 
Luneev, V.V. (1997). Prestupnost' XX veka. Mirovoj kriminologičeskij analiz [The 20th century Crime. World Criminal Analysis]. Moscow: Nauka.

Masagutov, R.M. (2004). Social'noe dominirovanie, viktimizaciâ i agressiâ zaklûčënnyh podrostkov [Social domination, victimization and aggression of the juvenile prisoners]. Social'naâ i kliničeskaâ psihiatriâ, 14 (3), 32-35.

Osipov, G.V., Levashov, V.K, \& Lokosov, V.V. (Eds.). (1997). Rossiâ u kritičeskoj čerty: vozroždenie ili katastrofa. Social'naâ $i$ socialno-političeskaâ situaciâ v Rossii v 1996 godu [Russia at a Critical Point: The Revival or a Catastrophe: The Social and SocioPolitical Situation in Russia in 1996]. Moscow: Respublika.

Petrenko, V.F., \& Kucherenko, V.V. (1998). Vzaimosvâz' èmocij i cveta [Interrelation of Emotions and Colour]. Vestnik Moskovskogo universiteta. Seriâ 14 "Psihologiâ," 3, 70-82.

Prestupnost' i pravonarušeniâ (1993-1997 gody) (1998). [Criminality and Offences (1993-1997)]. In Statističeskij sbornik [Statistical Bulletin]. Moscow: Glavnyj informacionnyj centr MVD Rossii.

Prestupnost' sredi nesoveršennoletnih v Rossii (1994-1998) (1999). [Juvenile Delinquency in Russia (1994-1998)]. In Statističeskij sbornik [Statistical Bulletin]. Moscow: Glavnyj informacionnyj centr MVD Rossii.

Ria-novosti [Ria-news] 9.14.2005. http://www.rian.ru/society/20050914/index14. html.

Shipunova, T.V. (2000). Kritičeskij analiz pričinnyh teorij deviantnosti [Critical Analysis of Causal Theories of Deviation] In A.O. Boronoev(Ed.), Problemy teoretičeskoj sociologii. Vyp. 3 [Problems of Theoretical Sociology. Vol. 3]. Saint Petersburg: SPbGU.

Sobkin, B., \& Kuznetsova, N. (1999). Dinamika deviantnogo povedeniâ podrostkov [Dynamics of Deviation in Behavior of Teenagers]. Osnovy bezopasnosti žizni. Naučno-metodičeskij žurnal, 10.

Sostoânie prestupnosti v Rossii za ânvar'-dekabr' 1998 goda (1999). [Criminality in Russia for January-December, 1998]. Moscow: MVD RF.

Urvantsev, L.P. (1981). Psihologiâ vospriâtiâ cveta: učebnoe posobie [Psychology of Colour Perception: The Methodical Guide]. Yaroslavl: ÂGU.

Zabryansky, G.I., \& Emelianova, L.V. (2000). Statistika prestupnosti nesoveršennoletnih $v$ Rossii: Analitičeskij obzor [Statistics of Junior Delinquency in Russia in 1998: Analytical Review]. Moscow: MOO Centr "Sudebno-pravovaâ reforma." 